\title{
Pandemic-Related Experiences and Psychosocial Risk Associations Among U.S. Medical Students
}

\author{
Nathaniel A. Jenkins,' Damion J. Grasso. ${ }^{2}$
}

\begin{abstract}
Background: Since the start of the COVID-19 global pandemic there has been a profound impact on the psychosocial health of medical professionals, with heightened risk reported on measures of depression, anxiety, and stress relative to non-healthcare professionals. However, there is limited data on the impact of COVID-19 on the psychosocial health of U.S. undergraduate medical students. The current cross-sectional study aims to examine associations between pandemic-related experiences and psychosocial risk among a sample of medical students attending a Northeastern U.S. allopathic medical school. Methods: One-hundred and seventy-nine students ( $42.6 \%$ of the study body) completed an online survey during the CoVID-19 pandemic that included sociodemographic characteristics, the 30-item Brief Epidemic-Pandemic Impacts Inventory (EPII-B), the 2-item Patient Health Questionnaire (PHQ-2), the 2item Generalized Anxiety Disorder (CAD-2), and the Primary Care PTSD Screen for DSM-5 (PC-PTSD-5). Results: Rates of serious adverse pandemic-related experiences (e.g., increased conflict, less physical activity, frequent substance use) were as high as $37.5 \%$. Students with a greater number of adverse pandemic-related experiences reported more time with COVID-19 positive patients and were more likely to screen positive for depression, anxiety, and PTSD $\left(r_{s}\right.$ from $0.25-0.34$, all ps $\left.<0.01\right)$. Conclusion: These findings suggest the need for other U.S. medical schools to evaluate and address medical student mental health during the COVID-19 public health crisis.
\end{abstract}

Key Words: COVID-19; Medical education; Professional Burnout; Depression; Anxiety (Source: MeSH-NLM).

\section{Introduction}

The World Health Organization declared COVID-19 a global pandemic on March 11, 2020. ${ }^{1}$ Since then, many aspects of daily life have drastically changed, with constraints on interpersonal relationships, work, home life, and mobility as a result of occurrences such as social distancing, virtual activities, furlough, increased contact with household members, less contact with extended family, forced quarantine, and government enforced lockdowns. Several studies thus far have linked pandemic stress to heightened risk for psychosocial impairment in the general population during this time. . $^{2,3}$ This effect seems to be pronounced for healthcare workers on the 'front-line', which may be partially attributed to long working hours, shortages of personal-protective equipment (PPE), emotional distress caring for COVID-19 patients, and the stigma associated with chronic potential exposure to the virus. 4,5

Medical students are important members of the healthcare sector. Even before COVID-19, previous studies have demonstrated that medical students tend to experience more mental health issues than the general population, such as higher rates of depression, anxiety, and burnout. ${ }^{6}$ This is thought to be attributed, at least in part, to the demanding curricula, pressure to pass exams, and emotional taxation. ${ }^{7}$ Despite medical students having greater access to mental health services, often provided by their respective institutions, research shows that they are less likely to access those services when compared to the general population, perhaps due to increased mental health stigma. ${ }^{8}$

Since medical students serve dual roles as both students and healthcare providers, it is likely that medical students may also have heightened risk for psychosocial impairment during this time. Special considerations for this group include observation of human suffering, alterations to pre-clinical/clinical training, changes in medical licensing exam policies, and the adjustment process into a high-risk workplace environment. One recent U.S. study determined that when compared to previous studies, medical students were scoring $61 \%$ higher on anxiety screenings (CAD-7) and $70 \%$ higher on depression screenings (PHQ-9) early in the pandemic. ${ }^{9}$ These findings align with data in other countries where the prevalence of depression, anxiety, and burnout of medical providers during the pandemic has been observed as significantly higher than prior to the pandemic. ${ }^{10,11}$

Despite these initial findings, the effect of COVID-19 on medical student mental health has not yet been sufficiently studied in the United States. Additionally, no studies thus far have utilized an inventory of pandemic-specific stressors to explore this topic in medical student samples. The current study employs a novel instrument called the Brief Epidemic-Pandemic Impacts Inventory Brief (EPII-B) to examine specific pandemic-related experiences across multiple domains of life (i.e., home life, work/environment, social activities, emotional/physical health). ${ }^{12}$ Recent studies have employed this tool and demonstrated its usefulness in linking psychosocial experiences with the COVID-19 pandemic for employees that work in direct patient care as well as for patients that frequent healthcare settings. ${ }^{13,14}$ By using this instrument, in combination with other standardized screening tools for depression, anxiety, and posttraumatic stress, we sought to further characterize how specific COVID-19 pandemic-related experiences among U.S. medical students link to associated psychosocial risk.

\section{Methods}

Study Design

During a 4-week period between February $23^{\text {rd }} 2021$ - March $23^{\text {rd }} 2021$, allopathic medical students from the University of Connecticut School of Medicine were invited via email to complete an online survey for a chance to win a $\$ 25$ gift card. Inclusion criteria for the study were to be a University of Connecticut School of Medicine student, be actively

B.S. University of Connecticut School of Medicine, Departments of Psychiatry and Pediatrics, Farmington, Connecticut, United States. 2 Ph.D. University of Connecticut School of Medicine, Departments of Psychiatry and Pediatrics, Farmington, Connecticut, United States

\section{Correspondence:}

Nathaniel A. Jenkins

Address: 200 Academic Way, Farmington, CT 06032, United States Email: njenkins.uconn@gmail.com
Editor: Francisco J. Bonilla-Escobar Student Editors: Johnmark Boachie, Brandon Belbeck \& Andrew Thomas Copyeditor: Leah Komer Proofreader: Nikoleta Tellios Layout Editor: Francisco J. Bonilla-Escobar
Submission: Aug 5, 2021 Revisions required: Aug 27; Nov 3, 2021 Received in revised form: Sep 5: Nov 10, 2021 Acceptance: Nov 14, 2021 Acceptance: Nov 14, 2021 Publication: Nov 23, 2021
Process: Peer-reviewed 
studying in the curriculum, and to give informed consent. There were no exclusion criteria. An email with the survey link was sent using a closed listserv only available to medical students at this school. The email was sent a total of four times during this period. The survey was administered using Qualtrics software in an anonymously. To prevent duplicate entries, participants were required to disclose any previous survey engagement. Endorsement of previous engagement resulted in survey termination. Additionally, students provided university issued email addresses. No email address was entered twice. At the completion of the survey, participants who were interested in the gift card were redirected to a separate Qualtrics survey that collected school-specific email addresses to ensure inclusion criteria. This data was kept separate from the main survey data and could not be matched. The University of Connecticut Health Center Institutional Review Board approved the study protocol (number $21 \mathrm{X}-148-2$ ) prior to distribution of the survey. Passive consent was obtained.

\section{Study Measures}

The survey began with confirmation that the participant had never taken the survey before, followed by a series of sociodemographic questions (medical school year, preferred gender, age, and race). sliding scales were used to estimate what percent of students' time in medical school was spent with patients, and specifically, pediatric, adult, geriatric, and COVID-19 positive patients.

The 30-item EPII-B assessed whether several pandemic-related experiences had occurred since the beginning of the pandemic and instructed participants to rate the impact of these experiences on a 5point scale ( $0=$ "Did not happen", 1= "Happened but no impact on me or my family", 2= "Some impact on me or my family", $3=$ "A lot of impact on me or my family", 4= "Extreme impact on me or my family"). A previous study using the longer 92-item Epidemic-Pandemic Impacts Inventory (EPII) supports the validity of this tool in characterizing pandemic-associated risk for depression, anxiety, and stress. ${ }^{13} \mathrm{~A}$ positive response (i.e., responding anything other than "Did not happen") was used to dichotomize each item for purposes of determining rates of occurrence. In addition, ratings on EPII-B items were tallied as a measure of perceived impact of positive experiences ( 2 items) and negative experiences (28 items). ${ }^{12}$ Internal consistency reliability was $\alpha=0.70$ and 0.80 for the EPII "positive impact" and "negative impact", respectively.

The 2-item Patient Health Questionnaire-2 (PHQ-2) is a well validated screening tool for Major Depressive Disorder (MDD). ${ }^{15}$ Likewise, the 2item Generalized Anxiety Disorder-2 (CAD-2) is a well validated screening tool for clinical anxiety. ${ }^{16}$ Additionally, the Primary Care PTSD Screen for DSM-5 (PC-PTSD-5) is a validated screening tool for posttraumatic stress disorder (PTSD). ${ }^{17}$ Screening positive on any one of the three screeners was examined as the primary outcome. As with all screening tests, a positive response indicates the need for further evaluation by a health professional and could not be used to determine a diagnosis.

\section{Statistical Analysis}

Descriptive statistics were used to understand the sociodemographic characteristics of the sample. Rates on EPII-B items were presented as the percent $(\%)$ of participants responding positively to each statement. Screening positive on any one or more of the three screeners (i.e., PHQ2, GAD-2, and PC-PTSD-5) was examined as the primary outcome. Spearman correlations, chi-square goodness-of-fit tests, and multivariate logistic regression were conducted using IBM SPSS software version $27 .{ }^{18}$ Bonferroni corrections were applied as appropriate to adjust for multiple comparisons.

\section{Results}

The survey was completed by 179 students ( $42.6 \%$ of 420 total enrolled medical students $)$. of the total $(n=179), 68.7 \%(n=123)$ were female,
$30.7 \%(n=55)$ were male, and $0.6 \%(n=1)$ were non-binary. The average age was 25.7 years old with a standard deviation of \pm 2.9 years. The same was comprised of first year $\left(\mathrm{M}_{1}\right)(n=44,24.6 \%)$, second year (M2) $(n=40,22.3 \%)$, third year $\left(\mathrm{M}_{3}\right)(n=54,30.2 \%)$, and fourth year (M4) $(n=41,22.9 \%)$ medical students. As such, 92 participants $(52.5 \%)$ were in pre-clinical education $\left(\mathrm{M}_{1}, \mathrm{M}_{2}\right)$ and $87(47.5 \%)$ were in clinical education $\left(\mathrm{M}_{3}, \mathrm{M}_{4}\right)$. Ethnic minorities represented $32.2 \%(n=57)$ of the sample. of all survey respondents, $27.7 \%(n=41)$ screened positive on the PHQ-2, $48.6 \%(n=72)$ on the GAD-2, and $24.3 \%(n=36)$ on the PCPTSD-5. A notable $53.4 \%(n=79)$ of medical students screened positive on one or more of the three mental health screening tools. This data is presented in Table 1

Table 1. Study Population Characteristics

\begin{tabular}{|c|c|c|c|}
\hline Characteristics & $\begin{array}{l}\text { Missing } \\
\mathrm{n}(\%)^{\mathrm{a}}\end{array}$ & Mean (SD) & $\begin{array}{l}\text { Percent } \\
(\%)^{b}\end{array}$ \\
\hline Age & $2(1.1)$ & $25.7(2.9)$ & \\
\hline Cender & 0 & & \\
\hline Female & & & 68.7 \\
\hline Male & & & 30.7 \\
\hline Non-binary & & & 0.6 \\
\hline Ethnic Minority ${ }^{c}$ & $2(1.1)$ & & 32.2 \\
\hline \multicolumn{4}{|l|}{ Medical Student Year } \\
\hline First & & & 24.6 \\
\hline Second & & & 22.3 \\
\hline Third & & & 30.2 \\
\hline Fourth & & & 22.9 \\
\hline \multicolumn{4}{|l|}{$\%$ time spent with patients } \\
\hline Overall & & $33.0(30.5)$ & 96.0 \\
\hline Pediatrics & & $10.1(19.8)$ & 54.2 \\
\hline Adult & & $26.8(28.4)$ & 83.8 \\
\hline Ceriatric & & $15.6(20.7)$ & 76.5 \\
\hline COVID+ & & $3.9(9.8)$ & 33.5 \\
\hline $\begin{array}{l}\text { PHQ-2 Depression Positive } \\
\text { Screen }\end{array}$ & $31(17.3)$ & & 27.7 \\
\hline $\begin{array}{l}\text { GAD-2 Anxiety } \quad \text { Positive } \\
\text { Screen }\end{array}$ & $31(17.3)$ & & 48.6 \\
\hline $\begin{array}{l}\text { Primary Care PTSD Positive } \\
\text { Screen }\end{array}$ & $31(17.3)$ & & 24.3 \\
\hline Any Positive Screen & $31(17.3)$ & & 53.4 \\
\hline
\end{tabular}

Legend: A total of 179 medical students at a U.S. allopathic medical school in the Northeast responded to the questionnaire. SD: Standard Deviation, No: number COVID+: COVID-19 positive, PHO-2: Patient Health Questionnaire 2-item Depression Screen, GAD-2: Generalized Anxiety Disorder 2-item Screen, PTSD: Posttraumatic Stress Disorder. ${ }^{a}$ The number and percentage of respondents that left a certain section of the questionnaire unanswered is represented in this column. ${ }^{b}$ Percent of those who responded (eg, excluding missing). Percentages may not sum up to 100 as a result of rounding. c "Ethnic Minority" representing a term used to describe self-reported nonwhite ethnicity.

Rates of adverse pandemic-related experiences among medical students were noteworthy. Several of these were significantly associated with screening positive for depression, anxiety, and/or posttraumatic stress (Table 2). Specifically, the strongest correlations (all ps $<0.002$ ) included (a) increased verbal/physical conflict among family and PTSD $\left(r_{s}=0.26\right)$, (b) not having the ability or resources to talk to or see family/friends while separated and PTSD $\left(r_{s}=0.27\right)$, (c) more frequent or severe mental health, sleep, or alcohol/substance use problems and depression $\left(r_{s}=0.40\right)$, anxiety $\left(r_{s}=0.49\right)$, and PTSD $\left(r_{s}=\right.$ $0.52)$, and (d) getting less exercise, spending more time sitting down, or eating more junk food and depression $\left(r_{s}=0.32\right)$ and PTSD $\left(r_{s}=0.27\right)$. Although not significant after Bonferroni correction, negative correlations were found between the two positive items and these measures. 
Table 2. Epidemic-Pandemic Impacts Inventory (EPII) Base Rates and Correlation with Perceived Stress, Depression, Anxiety, and Posttraumatic Stress

\begin{tabular}{|c|c|c|c|c|}
\hline \multicolumn{4}{|l|}{ Work, Education, and Training } & PTS \\
\hline $\begin{array}{l}\text { Had to work in close contact with people who } \\
\text { might be infected }\end{array}$ & 47.4 & 0.16 & 0.14 & $0.20^{*}$ \\
\hline $\begin{array}{l}\text { Provided direct care or services to people } \\
\text { who had COVID }\end{array}$ & 16.1 & 0.00 & -0.03 & -0.12 \\
\hline $\begin{array}{l}\text { Had an increase in workload or work } \\
\text { responsibilities }\end{array}$ & 16.0 & 0.19 & $.22^{*}$ & 0.09 \\
\hline $\begin{array}{l}\text { Laid off, furloughed, had to close a business, } \\
\text { or had reduced work hours }\end{array}$ & 14.8 & 0.03 & 0.13 & -0.03 \\
\hline \multicolumn{5}{|l|}{ Home Life } \\
\hline $\begin{array}{l}\text { Spent a lot more time taking care of a family } \\
\text { member most days }\end{array}$ & 6.1 & 0.04 & 0.17 & 0.12 \\
\hline $\begin{array}{l}\text { A child or teenager/young adult I care for } \\
\text { could not go to school or needed home } \\
\text { instruction }\end{array}$ & 5.4 & -0.06 & 0.01 & -0.08 \\
\hline $\begin{array}{l}\text { Increase in verbal or physical conflict with a } \\
\text { partner or spouse }\end{array}$ & 5.3 & 0.15 & 0.12 & 0.18 \\
\hline $\begin{array}{l}\text { hable to pay important large } \\
\text { utilities }\end{array}$ & 4.9 & -0.09 & 0.04 & -0.0 \\
\hline $\begin{array}{l}\text { Increase in verbal or physical conflict among } \\
\text { other family in my home }\end{array}$ & 4.8 & $21^{*}$ & 0.15 & $.26^{\star}$ \\
\hline $\begin{array}{l}\text { My family was unable to pay for or get } \\
\text { enough food or clean water }\end{array}$ & 2.8 & 0. & 0.09 & 12 \\
\hline $\begin{array}{l}\text { Had more conflict with or was harsher in } \\
\text { disciplining my child or children }\end{array}$ & 2.8 & $-0 . c$ & -0.02 & 0.08 \\
\hline $\begin{array}{l}\text { g was unavailable to } \\
\text { home when needed }\end{array}$ & 2.1 & 0.0 & 77 & 0.12 \\
\hline $\begin{array}{l}\text { My family had to move, relocate, was } \\
\text { evicted, or became homeless }\end{array}$ & 2 & -0.01 & c & 0.01 \\
\hline $\begin{array}{l}\text { My child[ren] had } n \\
\text { behavioral problems }\end{array}$ & 0.7 & 0.06 & .07 & 0.00 \\
\hline \multicolumn{5}{|l|}{ Emotional, Physical, and Social Health } \\
\hline $\begin{array}{l}\text { Cot less exercise, spent more time sitting } \\
\text { down, or ate more junk food }\end{array}$ & 37.5 & 0.32 & $0.24^{*}$ & 27 \\
\hline $\begin{array}{l}\text { Had to cancel or not attend important } \\
\text { celebrations, religious ceremonies, or } \\
\text { funerals }\end{array}$ & 35.9 & 0.01 & 0.00 & 0.02 \\
\hline $\begin{array}{l}\text { More frequent or severe mental health } \\
\text { problems, sleep, or use of alcohol or } \\
\text { substances }\end{array}$ & 15.4 & 0.4 & $0.49^{\star \star}$ & 0.52 \\
\hline $\begin{array}{l}\text { Important medical procedures cancelled or } \\
\text { unable to access care for serious condition }\end{array}$ & 13.9 & 0.11 & 0.15 & 0.01 \\
\hline sfied with & 7.8 & 0.09 & 0.11 & $.25^{*}$ \\
\hline $\begin{array}{l}\text { Could not get enough medicati } \\
\text { treatment for a chronic illness }\end{array}$ & 5.2 & 0.17 & 0.14 & $0.21^{*}$ \\
\hline $\begin{array}{l}\text { Trouble getting places due to less access to } \\
\text { public transportation or concerns about } \\
\text { safety }\end{array}$ & 3.6 & 0.13 & 0.05 & 0.07 \\
\hline $\begin{array}{l}\text { Did not have the ability or resources to talk } \\
\text { to or see family/friends while separated }\end{array}$ & 3.2 & 0.19 & .07 & $0.27^{\star}$ \\
\hline \multicolumn{5}{|l|}{ Quarantine and Infection Issues } \\
\hline $\begin{array}{l}\text { Isolated or quarantined due to possible } \\
\text { exposure to the disease, symptoms, or } \\
\text { increased risk }\end{array}$ & 31.0 & 0.06 & 0.13 & 0.21 \\
\hline $\begin{array}{l}\text { Limited physical closeness with my child or } \\
\text { loved one due to concerns of infection }\end{array}$ & 17.1 & 0.08 & 0.17 & 0.2 \\
\hline $\begin{array}{l}\text { Unable to be with family member } \\
\text { hospitalized, in a nursing home, or in critical }\end{array}$ & 11.9 & -0.07 & -0.01 & 0.02 \\
\hline Harassed/blamed for COVID-19, or denied & & & & \\
\hline $\begin{array}{l}\text { services/treatment for because of } \\
\text { race/ethnicity }\end{array}$ & 6.4 & 0 & 0.10 & 0.01 \\
\hline $\begin{array}{l}\text { d or family member died from } \\
\text { elated complications }\end{array}$ & 2.4 & 0.01 & -0.07 & 0.04 \\
\hline positive for & 1.6 & 0.02 & -0.01 & 0.06 \\
\hline \multicolumn{5}{|l|}{ Positive Change } \\
\hline $\begin{array}{l}\text { More quality time } \\
\text { to personal healt| }\end{array}$ & 19.0 & $-0.25^{n}$ & $-0.17^{*}$ & $-0.19^{*}$ \\
\hline $\begin{array}{l}\text { Found g } \\
\text { in my w }\end{array}$ & 18.1 & $-0.22^{\star}$ & -0.14 & -0.0 \\
\hline
\end{tabular}

Legend: Percent of respondents experiencing each EBII-B item and the subsequent correlation of that item with depression, anxiety, and PTSD screens. Item wording in some cases is abridged. PHQ: Patient Health Questionnaire 2-item Depression Screen, CAD: Ceneralized Anxiety Disorder 2-item Screen, PTS: Primary Care Posttraumatic Stress Disorder Screen. ${ }^{\star} p<.01,{ }^{\star *} p<.002$ (Bonferroni Correction)
Table 3. EPII Correlation with Percent Time with Patients Across Types

\begin{tabular}{|c|c|c|c|c|c|}
\hline \multicolumn{6}{|l|}{ Work, Education, and Training } \\
\hline $\begin{array}{l}\text { Had to work in close contact with } \\
\text { people who might be infected }\end{array}$ & 0.15 & 0.15 & 0.09 & 0.10 & $0.23^{*}$ \\
\hline $\begin{array}{l}\text { Provided direct care or services to } \\
\text { people who had COVID }\end{array}$ & $0.30^{* *}$ & 0.11 & $0.22^{*}$ & $0.18^{*}$ & $0.45^{\star *}$ \\
\hline $\begin{array}{l}\text { Had an increase in workload or work } \\
\text { responsibilities }\end{array}$ & -0.03 & -0.06 & -0.11 & -0.04 & 0.06 \\
\hline $\begin{array}{l}\text { Laid off, furloughed, had to close a } \\
\text { business, or had reduced work hours }\end{array}$ & 0.06 & 0.02 & 0.08 & 0.01 & 0.07 \\
\hline \multicolumn{6}{|l|}{ Home Life } \\
\hline $\begin{array}{l}\text { Spent a lot more time taking care of } \\
\text { a family member most days } \\
\text { A child or teenager/young adult I }\end{array}$ & -0.03 & -0.03 & -0.06 & 0.09 & 0.08 \\
\hline $\begin{array}{l}\text { care for could not go to school or } \\
\text { needed home instruction }\end{array}$ & 0.07 & 0.07 & 0.03 & 0.03 & -0.06 \\
\hline $\begin{array}{l}\text { Increase in verbal or physical } \\
\text { conflict with a partner or spouse }\end{array}$ & 0.15 & 0.05 & 0.07 & 0.07 & $0.21^{*}$ \\
\hline $\begin{array}{l}\text { My family was unable to pay important } \\
\text { large bills like rent or utilities }\end{array}$ & 0.10 & 0.07 & 0.05 & 0.09 & 0.18 \\
\hline $\begin{array}{l}\text { Increase in verbal or physical conflict } \\
\text { among other family in my home }\end{array}$ & 0.01 & 0.11 & 0.01 & 0.14 & 0.11 \\
\hline $\begin{array}{l}\text { My family was unable to pay for or } \\
\text { get enough food or clean water }\end{array}$ & 0.02 & -0.01 & 0.04 & 0.07 & $0.22^{\star}$ \\
\hline $\begin{array}{l}\text { Had more conflict with or was harsher in } \\
\text { disciplining my child or children }\end{array}$ & 0.09 & 0.06 & 0.09 & 0.09 & 0.12 \\
\hline Childcare or babysitting was & & & & & \\
\hline $\begin{array}{l}\text { unavailable to me or someone in } \\
\text { my home when needed }\end{array}$ & 0.19 & 0.16 & 0.18 & 0.11 & 0.15 \\
\hline $\begin{array}{l}\text { My family had to move, relocate, } \\
\text { was evicted, or became homeless } \\
\text { My child[ren] had more freguent or }\end{array}$ & 0.01 & -0.06 & 0.06 & 0.14 & 0.14 \\
\hline $\begin{array}{l}\text { severe behavioral problems or } \\
\text { emotional problems }\end{array}$ & 0.11 & 0.08 & 0.08 & 0.12 & 0.14 \\
\hline \multicolumn{6}{|l|}{ Emotional, Physical, and Social Health } \\
\hline $\begin{array}{l}\text { Cot less exercise, spent more time sitting } \\
\text { down, or ate more junk food } \\
\text { Had to cancel or not attend }\end{array}$ & -0.05 & -0.06 & 0.00 & 0.01 & 0.00 \\
\hline $\begin{array}{l}\text { important celebrations, religious } \\
\text { ceremonies, or funerals }\end{array}$ & 0.11 & 0.06 & 0.12 & $0.16^{*}$ & 0.17 \\
\hline $\begin{array}{l}\text { More frequent or severe mental } \\
\text { health problems, sleep, or use of } \\
\text { alcohol or substances } \\
\text { Important medical procedures }\end{array}$ & 0.00 & -0.03 & 0.03 & 0.14 & 0.05 \\
\hline $\begin{array}{l}\text { cancelled or unable to access care } \\
\text { for serious condition }\end{array}$ & -0.05 & -0.12 & -0.05 & 0.02 & 0.05 \\
\hline $\begin{array}{l}\text { Unable to access or was less } \\
\text { satisfied with mental health } \\
\text { treatment or therapy }\end{array}$ & 0.06 & 0.03 & 0.08 & 0.11 & 0.14 \\
\hline $\begin{array}{l}\text { Could not get enough medication or } \\
\text { medical treatment for a chronic } \\
\text { illness or pain } \\
\text { Trouble getting places due to less }\end{array}$ & 0.04 & -0.05 & 0.07 & 0.15 & $0.22^{*}$ \\
\hline $\begin{array}{l}\text { access to public transportation or } \\
\text { concerns about safety }\end{array}$ & 0.01 & 0.08 & 0.01 & 0.02 & 0.09 \\
\hline $\begin{array}{l}\text { Did not have the ability or resources } \\
\text { to talk to or see family/friends while } \\
\text { separated }\end{array}$ & 0.00 & -0.04 & 0.00 & $0.17^{\star}$ & 0.15 \\
\hline \multicolumn{6}{|l|}{ Quarantine and Infection Issues } \\
\hline $\begin{array}{l}\text { Isolated or quarantined due to } \\
\text { possible exposure to the disease, } \\
\text { symptoms, or increased risk }\end{array}$ & 0.01 & 0.07 & -0.09 & 0.02 & 0.15 \\
\hline $\begin{array}{l}\text { Limited physical closeness with my } \\
\text { child or loved one due to concerns } \\
\text { of infection } \\
\text { Unable to be with family member }\end{array}$ & 0.08 & -0.05 & -0.04 & 0.02 & 0.04 \\
\hline $\begin{array}{l}\text { hospitalized, in a nursing home, or } \\
\text { in critical condition }\end{array}$ & -0.07 & -0.09 & 0.01 & 0.09 & 0.13 \\
\hline $\begin{array}{l}\text { Harassed/blamed for COVID-19, or } \\
\text { denied services/treatment for } \\
\text { because of race/ethnicity } \\
\text { A close friend or family member }\end{array}$ & 0.19 & 0.19 & 0.16 & $0.25^{*}$ & $0.23^{*}$ \\
\hline $\begin{array}{l}\text { died from COVID-19 or related } \\
\text { complications }\end{array}$ & -0.08 & 0.03 & 0.02 & 0.09 & 0.09 \\
\hline $\begin{array}{l}\text { I or someone in my home tested } \\
\text { positive for COVID-19 and had } \\
\text { severe symptoms }\end{array}$ & -0.11 & -0.02 & -0.06 & 0.01 & 0.06 \\
\hline \multicolumn{6}{|l|}{ Positive Change } \\
\hline $\begin{array}{l}\text { More quality time together, paid } \\
\text { more attention to personal health, } \\
\text { or made new connections }\end{array}$ & -0.07 & 0.02 & -0.09 & -0.15 & -0.03 \\
\hline $\begin{array}{l}\text { Found greater meaning and was } \\
\text { more effective in my work, school, } \\
\text { or friendships than before }\end{array}$ & 0.06 & 0.16 & -0.02 & 0.01 & 0.11 \\
\hline
\end{tabular}

Legend: COVID+: COVID-19 positive, EPII: Epidemic-Pandemic Impacts Inventory. ${ }^{\star} p<.01,{ }^{* *} p<.002$ (Bonferroni Correction) 
Table 4. Correlation Matrix

\begin{tabular}{|c|c|c|c|c|c|c|c|c|c|c|c|}
\hline \multirow{2}{*}{$\begin{array}{l}\text { Questionnaire } \\
\text { EPII Ave. Negative Impact }(r)\end{array}$} & \multicolumn{2}{|c|}{$\begin{array}{l}\text { EPII Ave. } \\
\text { Negative } \\
\text { Impact }\end{array}$} & \multicolumn{2}{|c|}{$\begin{array}{l}\text { EPII Ave. } \\
\text { Positive } \\
\text { Impact }\end{array}$} & \multicolumn{2}{|c|}{$\begin{array}{l}\text { \% Time w/ } \\
\text { Patients }\end{array}$} & \multirow[t]{2}{*}{$\begin{array}{l}\text { \% Time w/ } \\
\text { COVID } \\
\text { Patients }\end{array}$} & \multicolumn{2}{|c|}{$\begin{array}{l}\text { PHQ-2 } \\
\text { Positive } \\
\text { Screen }\end{array}$} & \multicolumn{2}{|c|}{$\begin{array}{l}\text { GAD-2 Positive } \\
\text { Screen }\end{array}$} \\
\hline & -- & & & & & & & & & & \\
\hline EPII Ave. Positive Impact $(r)$ & .02 & & -- & & & & & & & & \\
\hline \% Time w/ Patients ( $r$ ) & .07 & & -.02 & & -- & & & & & & \\
\hline \% Time w/ COVID Patients ( $r$ ) & .29 & $\star \star$ & .05 & & .55 & $\star \star$ & -- & & & & \\
\hline PHQ-2 Positive Screen $\left(r_{s}\right)$ & .25 & ** & -.26 & $\star \star$ & -.05 & & .03 & -- & & & \\
\hline GAD-2 Positive Screen $\left(r_{s}\right)$ & .31 & $\star \star$ & -.18 & * & -.01 & & -.11 & .43 & $\star \star$ & -- & \\
\hline PC-PTSD Positive Screen $\left(r_{s}\right)$ & .34 & ** & -.15 & & -.00 & & .01 & .49 & ** & .39 & $\star *$ \\
\hline
\end{tabular}

Legend: Ave: Average, PHQ-2: Patient Health Questionnaire 2-item Depression Screen, GAD-2: Ceneralized Anxiety Disorder 2-item Screen, PC-PTSD: Primary Care Posttraumatic Stress Disorder Screen. $r_{s}=$ Spearman Correlation. ${ }^{*} p<.05 .{ }^{* *} p<.01$

Correlations between EPII items and student-reported percentage of time spent with various patient populations during the past year of medical school training are represented in Table 3. Table 4 presents correlations between the two EPII-B impact variables (i.e., average negative and positive impact), positive screens, and estimated percentage of time spent with patients. Perceived negative impact across adverse experiences was significantly associated (all ps $<0.01$ ) with screening positive for depression $\left(r_{s}=0.25\right)$, anxiety $\left(r_{s}=0.31\right)$, or PTSD $\left(r_{s}=0.34\right)$, and greater estimated time spent with COVID-19 positive patients $\left(r_{s}=0.29\right)$. Perceived positive impact across positive change experiences was significantly negatively correlated with positive screens on depression $\left(r_{s}=0.26, p s<0.01\right)$ and anxiety $\left(r_{s}=0.18\right.$, ps < 0.01 ).

Table 5 presents results from a multivariate logistic regression testing whether perceived negative and positive impact predict a positive screen on at least one of the three screens (depression, anxiety, PTSD), controlling for age, sex, ethnic minority status, and estimated time spent with COVID-19 positive patients. In the final step of the model, significant predictors included male sex, greater estimated time spent with COVID-19 positive patients, and perceived negative impact of pandemic-related experiences. Perceived positive impact was not significantly predictive of the outcome.

\section{Discussion}

The current findings suggest that high rates of adverse pandemic related experiences in medical students are associated with indicators of psychosocial impairment (Figure 1). Nearly half of the sample screened positive for depression, anxiety, or PTSD on validated screening instruments during the pandemic $(n=79,53.4 \%)$. Several experiences on the EPII-B were associated with increased risk of screening positive on one of these screening tools. These included worsening sleep, less exercise, poor eating habits, and the inability to talk to or see family/friends. Although not addressed in the current study, it is possible that these effects may be influenced by government "lockdown" orders, quarantining, and the increase in online-learning during this time. Poor sleep quality, physical activity, diet, and social isolation are important predictors of mental health in young adults. ${ }^{19}$. ${ }^{20}$ For example, a medical student in pre-clinical education using virtualonly learning methods may have felt more isolated and unable to exercise, socialize, etc. In a recent study, online learning appears to be an obstacle for medical students due to difficulty adapting to new learning styles, inaccessibility of educators, and poor communication with other learners. ${ }^{21}$ Perhaps these challenges, combined with a sudden shift in routine, may have contributed to the worsening mental health in this sample of students.

Table 5. Multivariate logistic regression testing whether perceived negative and positive impact predict a positive screen on at least one of the three screens (depression, anxiety, PTSD).

\begin{tabular}{|c|c|c|c|c|c|c|c|}
\hline \multirow{2}{*}{ Variables } & \multirow{2}{*}{ B } & \multirow{2}{*}{ SE } & \multirow{2}{*}{ Wald } & \multirow{2}{*}{$p$-value } & \multirow{2}{*}{$O R$} & \multicolumn{2}{|c|}{$95 \% \mathrm{Cl}$} \\
\hline & & & & & & Upper & Lower \\
\hline \multicolumn{8}{|l|}{ Step One } \\
\hline Age & 0.09 & 0.09 & 1.15 & .283 & 1.10 & 0.92 & 1.30 \\
\hline Sex (Male) & -0.77 & 0.40 & 3.72 & .054 & 0.47 & 0.21 & 1.01 \\
\hline Ethnic Minority & -0.33 & 0.40 & 0.66 & .418 & 0.72 & 0.33 & 1.59 \\
\hline Time w/ COVID Pts. & -0.06 & 0.03 & 5.23 & $.022^{*}$ & 0.94 & 0.89 & 0.99 \\
\hline \multicolumn{8}{|l|}{ Step Two } \\
\hline Age & 0.12 & 0.09 & 1.49 & .222 & 1.13 & 0.93 & 1.36 \\
\hline Sex (Male) & -0.99 & 0.44 & 5.13 & $.023^{*}$ & 0.37 & 0.16 & 0.88 \\
\hline Ethnic Minority & -0.53 & 0.44 & 1.47 & .226 & 0.59 & 0.25 & 1.39 \\
\hline Time w/ COVID Pts. & -0.10 & 0.03 & 9.72 & $.002^{*}$ & 0.90 & 0.85 & 0.96 \\
\hline EPII Negative Impact & 2.42 & 0.62 & 15.01 & $<.001^{\star *}$ & 11.24 & 3.31 & 38.23 \\
\hline \multicolumn{8}{|l|}{ Step Three } \\
\hline Age & 0.10 & 0.10 & 0.94 & .333 & 1.10 & 0.91 & 1.33 \\
\hline Sex (Male) & -1.01 & 0.44 & 5.25 & $.022^{\star}$ & 0.36 & 0.15 & 0.86 \\
\hline Ethnic Minority & -0.42 & 0.44 & 0.91 & .340 & 0.66 & 0.28 & 1.56 \\
\hline Time w/ COVID Pts. & -0.09 & 0.03 & 8.22 & $.004^{*}$ & 0.91 & 0.86 & 0.97 \\
\hline EPII Negative Impact & 2.44 & 0.63 & 3.66 & $<.001^{\star \star}$ & 11.42 & 3.32 & 39.26 \\
\hline EPII Positive Impact & -0.36 & 0.19 & 3.66 & .056 & 0.70 & 0.49 & 1.01 \\
\hline
\end{tabular}

Legend: COVID Pts: COVID-19 patients, EPII: Epidemic-Pandemic Impacts Inventor, B: beta-coefficient, SE: standard error, OR: 0dds Ratio. ${ }^{\star} p<.05 .{ }^{\star *} p<.01$ 
Figure 1. Conceptual Diagram of Pandemic-Related Experiences and Mental Health in Medical Students

Pandemic-Related Adverse Experiences

close contact with infected patients

Increased conflict at home

Limited physical closeness with loved ones

Unhealthy lifestyle changes

Demands of Medical School Curriculum

Demanding curriculum

Medical licensing exam pressure

Emotional taxation

Preexisting Mental Health Difficulties

edical Student

Mental Health Risk

Medical School Response

Easily accessible mental health services

curriculum adjustment

Return to in-person classes

Students who screened positive for depression, anxiety, or PTSD were also more likely to screen positive for at least one other disorder. Other studies using the PHQ-2 and GAD-2 pre-pandemic have reported rates of positive depression and anxiety screens in medical students to be $16.4 \%^{22}$ and $25.7 \%^{23}$, respectively. Using the same screens during the pandemic, we found higher rates, with $27.7 \%$ of students screening positive for depression and $48.6 \%$ screening positive for anxiety. Although it is not possible to attribute these higher rates to the pandemic, associations between adverse pandemic-related experiences and these measures suggest higher risk during this time.

Although few pandemic-related experiences were significantly associated with estimated time spent with COVID-19 positive patients, average perceived negative impact across experiences was significantly associated with time spent with COVID-19 positive patients (Table 3). This aligns with research highlighting increased stress faced by healthcare providers during the pandemic. However, while perceived negative impact was significantly associated with screening positive on at least one of the screeners, estimated time spent with COVID-19 positive patients was not. It is plausible that the increased risk of infection associated with physical proximity to COVID-19 positive

\section{References}

1. Cucinotta D, Vanelli M. WHO Declares COVID-19 a Pandemic. Acta Biomed. 2020 Mar 19;91(1):157-160.

2. Wang C, Pan R, Wan X, Tan Y, Xu L, Ho CS, et al. Immediate psychological responses and associated factors during the initial stage of the 2019 coronavirus disease (COVID-19) epidemic among the general population in China. Int J Environ Res Public Health. 2020 Mar 6;17(5):1729. patients and/or fear of infecting others exacerbates the experience of stress among clinic-naïve medical students.

The experiences of medical students during the pandemic, however, was not uniform. Given that a small percentage of participants with positive occurrences (i.e., spending more quality time with others or finding greater meaning in school/work) appeared to have less depression and anxiety, this could be attributed to additional factors. For example, certain psychosocial factors during the pandemic may have buffered associated risk of mental health impairment for some medical students. It is difficult to determine from this study what these protective factors may be and how they might buffer associated risk. Possible factors contributing to this phenomenon may include a student's living arrangement (e.g., residing with a parent vs. roommate vs. significant other) and opportunities to continue to engage in activities and attending to personal health during the pandemic. Several studies have demonstrated that certain behaviors such as increased phone use, decreased physical activity, and reduced inperson social interaction among U.S. college students during the pandemic are associated with higher rates of depression and anxiety. ${ }^{24,25}$ Although published literature on these associations as it pertains specifically to medical students is limited, perhaps students who were more physically active or spent more time with family during the transition to virtual-only learning fared better than peers who did not.

These study findings should be interpreted in the context of several limitations. While the response rate was moderate, it was likely influenced by responder bias. Notably, the survey was completed by a greater number of female, rather than male or non-binary, students. In addition, it was conducted at a single U.S. allopathic medical school and as such, the data may be less generalizable. As is inherent with quantitative survey research, questionnaire design may have contributed to oversimplification of participant lived experience. Another limitation was that our modest sample size prevented more sophisticated statistical analysis and limited the number of comparisons possible; e.g., differential effects by class year and race. Finally, because this is a cross-sectional study, associations are correlational and directionality cannot be determined. Given the nature of the pandemic, no control group could be established and therefore external comparisons in this special population are restricted.

This cross-sectional study demonstrates high rates of adverse pandemic-related experiences in medical students during the COVID-19 pandemic. It joins the small but growing reports of worsening medical student anxiety, depression, and PTSD during this time. To our knowledge, this is the first study to examine pandemic-related experiences in a medical student population using a tool designed to assess specific changes across life domains due to COVID-19. It underscores the need for medical school administrators to be responsive and proactive in addressing the growing concern of psychosocial impairment among medical students. Potential improvements might include free, or reduced cost, ready access oncampus mental health services, adjustment in the medical curriculum to lower student stress, and encouragement of peer support. 
5. Pappa S, Ntella V, Giannakas T, Giannakoulis VG, Papoutsi E, Katsaounou P. Prevalence of depression, anxiety, and insomnia among healthcare workers during the COVID-19 pandemic: A systematic review and meta-analysis. Brain Behav Immun. 2020 Aug;88:901-907.

6. Bergmann C, Muth T, Loerbroks A. Medical students' perceptions of stress due to academic studies and its interrelationships with other domains of life: a qualitative study. Med Educ Online. 2019 Apr;24(1):1603526.

7. Wolf TM. Stress, coping and health: enhancing well-being during medical school. Med Educ. 1994 Jan;28(1):8-17.

8. Schwenk TL, Davis L, Wimsatt LA. Depression, stigma, and suicidal ideation in medical students. JAMA. 2010 Sept 15;304(11):1181-1190.

9. Halperin SJ, Henderson MN, Prenner S, Grauer JN. Prevalence of Anxiety and Depression Among Medical Students During the Covid-19 Pandemic: A CrossSectional Study. J of Med Educ and Curric Dev. 2021 Feb 15;8:2382120521991150.

10. Saraswathi I, Saikarthik J, Senthil Kumar K, Madhan Srinivasan K, Ardhanaari M, Gunapriya R. Impact of COVID-19 outbreak on the mental health status of undergraduate medical students in a COVID-19 treating medical college: a prospective longitudinal study. PeerJ. 2020 Oct 16;8:e10164.

11. Stacey A, D'Eon M, Madojemu G. Medical student stress and burnout: Before and after COVID-19. Can Med Educ J. 2020 Dec;11(6):204-205.

12. Grasso DJ, Briggs-Cowen MJ, Ford JD, Carter AS. Epidemic-Pandemic Impacts Inventory. University of Connecticut School of Medicine. 2020.

13. Grasso DJ, Briggs-Gowen MJ, Carter AS, Goldstein BL, Ford JD. Profiling COVIDrelated experiences in the United States with the Epidemic-Pandemic Impacts Inventory: Linkages to psychosocial functioning. Brain and Behav. 2021 Jul 3;11(8):e02197.

14. Shah A, Darling M, Arstein-Kerslake 0, Morgan T, Tovrea AV, Young J, et al Measuring the Impact of COVID-19 on Siyan Mental Health Patients Using the Epidemic-Pandemic Impacts Inventory: Survey Study. JMIR Form Res. 2021 Jul 29;5(7):e29952.

15. Kroenke K, Spitzer RL, Williams JB. The Patient Health Questionnaire-2: validity of a two-item depression screener. Med Care. 2003 Nov;41(11):1284-1292.
16. Kroenke K, Spitzer RL, Williams JBW, Monahan PO, Löwe B. Anxiety disorders in primary care: prevalence, impairment, comorbidity, and detection. Ann Intern Med. 2007 Mar 6;146(5):317-325.

17. Prins A, Bovin MJ, Smolenski DJ, Marx BP, Kimerling R, Jenkins-Guarnieri MA, et al. The Primary Care PTSD Screen for DSM-5 (CS-PTSD-5): Development and Evaluation Within a Veteran Primary Care Sample. J Gen Intern Med. 2016 Oct;31(10):1206-1211.

18. IBM Corp. Released 2020. IBM SPSS Statistics for Windows, Version 27.0. Armonk, NY: IBM Corp.

19. Wickham SR, Amarasekara NA, Bartonicek A, Conner TS. The Big Three Health Behaviors and Mental Health and Well-Being Among Young Adults: A CrossSectional Investigation of Sleep, Exercise, and Diet. Front Psychol. 2020 Dec 10;11:3339.

20. Christiansen J, Qualter P, Friis K, Pedersen SS, Lund R, Andersen CM, et al Associations of loneliness and social isolation with physical and mental health among adolescents and young adults. Perspect Pub Health. 2021 Jul;141(4):226236.

21. Baticulon RE, Sy JJ, Alberto NR, Baron MB, Mabulay RE, Rizada LG, et al. Barriers to Online Learning in the Time of COVID-19: A National Survey of Medical Students in the Philippines. Med Sci Educ. 2021 Feb 24;31:615-626.

22. Mousa OY, Dhamoon MS, Lander S, Dhamoon AS. The MD Blues: UnderRecognized Depression and Anxiety in Medical Trainees. PLoS One. 2016 Jun 10;11(6):e0156554.

23. MacLean L, Booza J, Balon R. The Impact of Medical School of Student Mental Health. Acad Psychiatry. 2016 Feb;40(1):89-91.

24. Huckins JF, DaSilva AW, Wang W, Hedlund E, Rogers C, Nepal SK, et al. Mental Health and Behavior of College Students During the Early Phases of the COVID19 Pandemic: Longitudinal Smartphone and Ecological Momentary Assessment Study. J Med Internet Res. 2020 Jun 17;22(6):e20185

25. Son C, Hegde E, Smith A, Wang X, Sasangohar F. Effects of COVID-19 on College Students' Mental Health in the United States: Interview Survey Study. J Med Internet Res. 2020 Mar 3;22(9):e21279.

\section{Acknowledgments \\ None.}

Conflict of Interest Statement a Funding

The Authors have no conflicts of interest to disclose. The research presented in this manuscript was funded by a University of Connecticut School of Medicine research stipend.

\section{Author Contributions}

Conceptualization, Funding Acquisition, Investigation, Project Administration, Resources, Visualization, ¿t Writing - Original Draft Preparation: NAJ. Data Curation, Formal Analysis, Software, a Supervision: DJG. Methodology, Validation, at Writing - Review at Editing: NAJ at DJC.

Cite as

Jenkins NA, Grasso DJ. Pandemic-Related Experiences and Psychosocial Risk Associations Among U.S. Medical Students. Int J Med Students. 2021 0ctDec;9(4):288-293.

This work is licensed under a Creative Commons Attribution 4.0 International License

ISSN 2076-6327

This journal is published by the University Library System, University of Pittsburgh as part of the Digital Publishing Program and is co-sponsored by the University of Pittsburgh Press. 